\title{
Knowledge, practices and attitudes of physicians towards evidence- based medicine in Egypt
}

Amira Abdel-Kareem, ${ }^{1}$ Ibrahim Kabbash, ${ }^{1}$ Shima Saied ${ }^{1}$ and Abdelaziz Al-Deeb ${ }^{1}$

Public Health and Community Medicine, Faculty of Medicine, Tanta University, Tanta, Egypt. (Correspondence to: Ibrahim Kabbash: iafkabbash@ gmail.com; Ibrahim.kabbash@med.tanta.edu.eg).

\begin{abstract}
Background: Evidence-based medicine help clinicians deal with information overload, to distribute healthcare resources more equitably, help reduce healthcare costs, and justify treatment choices to the public.

Aims: This study aimed to assess evidence-based medicine (EBM) knowledge, practices and attitudes among physicians in Tanta University hospital, Tanta, Egypt.

Methods: A cross-sectional study was used. Collection of data was by a self-administrated questionnaire distributed to 398 physicians in different specialties during 2017.

Results: Response rate was 93.6\%. More than half (61.3\%) of participants reported Pub Med as used in decision-making. Physicians with good knowledge of EBM represented $10.5 \%$, those with fair knowledge represented $54 \%$, and those with poor knowledge represented $35.5 \%$. Regarding attitudes towards EBM, $76.4 \%$ of study participants welcomed the current promotion of EBM; 81.4\% thought that it useful to use research findings in daily management of patients; and $89.9 \%$ thought that practicing EBM improved patient outcomes. More than half of participants (55.8\%) had attended courses related to EBM, but only $6.8 \%$ had attended courses related to critical appraisal. The majority of participants (97\%) had access to the World Wide Web. Barriers reported by participants that interfere with EBM practice were patient overload (68.1\%), lack of time (60.1\%), colleagues' attitudes (47\%), lack of skills (46.7\%), and fear of criticism (44.5\%).
\end{abstract}

Conclusions: Most participants in this study have a positive attitude towards EBM, have a fair knowledge of it, but poor practices. EBM should be integrated in the curriculum of both undergraduate and postgraduate studies, and EBM training courses provided to residents to ensure correct application of EBM in daily practice.

Keywords: evidence-based medicine, medical students, KAP, Egypt

Citation: Abdel-Kareem A; Kabbash I; Saied S; Al-Deeb A. Knowledge, practices and attitudes of physicians towards evidence-based medicine in Egypt. East Mediterr Health J. 2019;25(2):82-89. https://doi.org/10.26719/emhj.18.010

Received: 30/12/17; accepted: 05/06/18

Copyright (C) World Health Organization (WHO) 2019. Some rights reserved. This work is available under the CC BY-NC-SA 3.0 IGO license (https:// creativecommons.org/licenses/by-nc-sa/3.0/igo).

\section{Introduction}

Evidence-based medicine (EBM) as a new paradigm for medical practice involves integrating the best available external clinical evidence with individual clinical expertise and use of individual patient's rights and preferences in clinical decision-making. Thus, the ability to critically appraise literature and assess its applicability is identified as integral to the practice of EBM (1). Evidence-based practice is the process of care for the patient, which takes into account his or her preferences and actions, the clinical resources available, and current and applicable scientific evidence, under the clinical expertise and training of the health-care provider (2).

Competent physicians use both individual clinical expertise as well as the best available external evidence (3). The benefits of EBM help clinicians deal with information overload, to distribute health care resources more equitably, help reduce healthcare costs, and justify treatment choices to the public. The goal is to improve quality of care by promoting effective practices and encourage clinicians have to try new scientific methods and discard ineffective practices (4).

In Egypt, relatively few studies (5-7) have been carried out to assess awareness demonstrated by health care physicians towards evidence-based medicine, the ability to access and interpret evidence, the barriers to moving from opinion-based to evidence-based practice, and the additional support necessary to incorporate evidence. This study was conducted to assess knowledge, attitudes and practices regarding EBM among physicians in Tanta University Hospitals in Tanta, Egypt, and identify barriers to EBM.

\section{Methods}

A cross-sectional study was performed in Tanta University Hospitals, which has 1962 beds providing secondary and tertiary healthcare services to 559532 patients per year. The total number of working physicians is 2138 (8). The study subjects were physicians working at Tanta University Hospitals based on the following inclusion criteria: residents, demonstrators, and assistant lecturers working at different departments of Tanta University Hospitals. Exclusion criteria included: physicians who spent $<3$ months in the job, and those who were on vacation during the whole period of study.

The sample size was calculated using Epi info 7, software developed by Center for Disease Control \& 
Prevention $(C D C)$ and the World Health Organization (WHO). The Calculated number was 384 physicians (CI $95 \%$ ), and expected outcome (total score of knowledge) was estimated at $50 \%$ with a $5 \%$ margin of error. The sample was obtained by one stage stratified sampling method. The departments were divided into two different strata; medical stratum and surgical stratum. The total sample size was divided by weight of total population of each stratum. In the medical stratum the total sample was 225 physicians while in the surgical stratum the total sample was 173 physicians. Departments were randomly selected from each stratum.

Data were collected from physicians using a selfadministered questionnaire. The valid and reliable questionnaire used by McColl et al. 1998 (9) and modified by Boulus et al. 2013 (6) was adopted. The questionnaire consists of the following sections:

1. Socio-demographic data

2. Knowledge of physicians

3. Attitude of physicians towards evidence-based medicine.

4. Questions to describe practicing of $E B M$

5. Perceived major barriers to practicing EBM in medical practice.

The questionnaire was sent to five experts for testing for validity. A pilot study was done on 20 physicians not included in the study and Cronbach's alpha was found to be 0.853 . The questionnaire was distributed to all residents, demonstrators and assistant lectures of the included medical and surgical departments. Out of 425 questionnaires distributed to physicians, 398 questionnaires were completed. Only 12 questionnaires were returned unanswered and were counted as 'no response'. Fifteen questionnaires were not returned (93.6\% response rate). The scoring system of the questionnaire (10) was as follows:

\section{A. Knowledge scoring:}

Knowledge assessment consisted of 14 items (seven items to determine awareness of physicians with journal sites and seven items to reveal awareness with statistical terms used in scientific papers). Each item had a four response format. Subscale scores ranging from 0 to 3 were obtained by summing the items in each subscale and calculating the mean of score percentage. Total knowledge score ranged from 0 to 42 . Knowledge score was divided into three tertiles; the first tertile represented poor, the second tertile represented fair, and the third tertile represented good knowledge.

\section{B. Attitude scoring (10):}

Attitude assessment consisted of three items with 5-Likert-scale format as zero "strongly unwelcoming" to 4 "strongly welcoming". Subscale score was obtained by summing the items and mean score percentage was calculated. Total attitude score ranged from zero to 12 . The attitude score was divided into two halves; the first half represented negative, and the second half represented positive attitude.

\section{Practice scoring:}

Practice assessment consisted of five questions. First two questions addressed any previous training and was scored as (0) for no attendance and (1) for attending. The third question asked about accessibility to World Wide Web and was scored as (o) for "No" and (1) for "Yes". The fourth question asked about using the World Wide Web in clinical decision-making and was scored (o) for "No" and (1) for "Yes". The fifth question asked about reading of medical journals and was scored as the following (o) for "do not read any journals", (1) for "read occasionally", (2) for "read on demand", and (3) for "read regularly". Total practice score ranged from 0 to 7 . The mean score percentage was calculated and the score was divided into three tertiles; the first tertile represented poor, the second tertile represented fair, and the third tertile represented good practice.

\section{Statistical Analysis}

Analysis of data was performed using Statistical Package for Social Sciences (SPSS ${ }^{\circledR}$ ) version 21 (IBM, Armonk, NY; United States of America). Qualitative data were described using number and percent. Quantitative data were presented as mean and standard deviation. Chi square test was used for comparison of subcategories. $\mathrm{P}<$ 0.05 was adopted as the level of significance.

\section{Ethical considerations}

Approval for the research was obtained from the ethical committee of Tanta Faculty of Medicine before starting the study. Subjects were informed about the purpose of study and benefits of participating in it. Verbal consent was obtained from subjects to participate in the study. Confidentiality and privacy were guaranteed during the whole period of study.

\section{Results}

Table 1 shows socio-demographic characteristics of study participants. Table 2 shows that the highest reported resources as "used in decision-making" among participants were Pubmed (61.3\%), Cochrane database for systematic review (10.1\%), and EBM from BMJ Publishing Group $(5.5 \%)$. Table 3 shows that more than one third $(35.3 \%)$ of study participants had poor knowledge and more than half of them (53.7\%) had fair knowledge, and only $10.5 \%$ of them had good knowledge. The table also reveals that job grade, specialty, and previous training concerning EBM had a statistically significant effect on knowledge score distribution among study participant.

Table 4 shows that $93.2 \%$ of participants had a positive attitude towards EBM, while only $6.8 \%$ of them had a negative attitude. Gender, job grade, specialty, previous qualifications, and previous training concerning EBM had a statistically significant effect on attitude scoring among study participants.

Table 5 shows that more than one-half of the 
participants attended EBM courses, while 6.8\% attended critical appraisal courses. Only $3.0 \%$ of participants did not have access to World Wide Web. Among those who had accessibility, 87.7\% used it in clinical decisionmaking. The percentage of study participants reading medical journals was $73.1 \%$. More than one half of the participants (54.5\%) reported their EBM practice as less than $50 \%$, and only $8.8 \%$ reported their EBM practice more than $75 \%$. The best educational method to move towards EBM according to participants' opinion was the case review and discussion (87.7\%), followed by workshops for training physicians $(84.2 \%)$, and lastly the integration of EBM into undergraduate courses (75.4\%). The major barriers perceived were patient overload (68.1\%), followed by lack of time $(60.1 \%)$, colleagues' attitude $(47 \%)$, lack of skills ( $46.7 \%)$, and lastly fear of criticism (44.5\%).

Table 6 shows that more than half (58.5\%) of study participants had a poor practice score and one third (33.2\%) of them had a fair practice score, and only $8.3 \%$ of them had a good practice score. The table also reveals that job grade, and specialty had a statistically significant effect on practice score distribution among the study participants.

\section{Discussion}

Regarding the knowledge of various EBM resources, the majority of study participants were aware of PubMed (Medline). Similar results were obtained by Risahmawati et al. (2011), which indicated that in Japan $90 \%$ of participants were aware of PubMed; moreover, it was the only resource among all EBM that was reported as used during clinical decision-making (10). However, the study conducted by Hassan et al. (2014) reported that only one half of the participants (50.9\%) were aware of Pubmed (7).

This study showed that $60.5 \%$ of participants were aware of BMJ Publishing Group. Similar results were obtained by Al-Kubaisi et al. (2010) in which BMJ awareness represented $62.2 \%$ of the participants, followed by Qatar Medical Journal at 40\% (11). The EBM from BMJ awareness in our study was higher than the study of Abd AL-Magied et al. (2013) and Hassan et al. (2014) in which only $28.6 \%$ and $27.3 \%$, respectively reported awareness of that resource $(5,7)$. In addition, $5.5 \%$ of participants had previously used EBM from BMJ in decision-making. This did not coincide with the study conducted in the Islamic Republic of Iran by Rashidbeygi and Sayehmiri (2013), which showed that $8.5 \%$ of participants used EBM from BMJ Publishing Group to support the process of decision-making (12).

Physicians' awareness percentage of clinical evidence in our results was $46.7 \%$. This varied with results from Hassan et al. (2014), which showed that only $29.1 \%$ of participants were aware (7). In addition, the studies conducted by Abd Al-Magied et al. (2013) and Boulus et al. (2013) reported that participants' awareness of clinical evidence websites were $30 \%$ and $31.6 \%$, respectively $(5,6)$. This can be attributed to the observation that our study participants had received training during both undergraduate and postgraduate curricula about EBM

\begin{tabular}{|c|c|c|}
\hline Characteristics & $n=398$ & $\%$ \\
\hline \multicolumn{3}{|l|}{ Age } \\
\hline $25-$ & 161 & 40.5 \\
\hline $28-$ & 122 & 30.7 \\
\hline $31-$ & 115 & 28.8 \\
\hline Range & \multicolumn{2}{|c|}{$25-34$} \\
\hline Mean \pm S.D & \multicolumn{2}{|c|}{$28.9 \pm 2.7$} \\
\hline \multicolumn{3}{|l|}{ Gender } \\
\hline Male & 213 & 53.0 \\
\hline Female & 185 & 47.0 \\
\hline \multicolumn{3}{|l|}{ Job } \\
\hline Resident & 188 & 47.2 \\
\hline Demonstrator & 61 & 15.3 \\
\hline Assistant lecturer & 149 & 37.5 \\
\hline \multicolumn{3}{|l|}{ Specialty } \\
\hline Medical & 225 & 56.0 \\
\hline Surgical & 173 & 44.0 \\
\hline \multicolumn{3}{|c|}{ Years since graduation } \\
\hline$<2$ & 15 & 3.8 \\
\hline $2-$ & 125 & 31.4 \\
\hline $4-$ & 108 & 27.1 \\
\hline $6-$ & 60 & 15.1 \\
\hline $8-$ & 66 & 16.6 \\
\hline 10 & 24 & 6.0 \\
\hline Range & \multicolumn{2}{|c|}{$1-12$} \\
\hline Mean \pm S.D & \multicolumn{2}{|c|}{$5.1 \pm 2.7$} \\
\hline \multicolumn{3}{|c|}{ Qualifications or fellowships } \\
\hline None & 374 & 94.0 \\
\hline USMLE & 10 & 2.5 \\
\hline MRCP & 10 & 2.5 \\
\hline MRCS & 4 & 1.0 \\
\hline
\end{tabular}

and its resources. Our study was also conducted three years later when awareness of EBM resources and its availability had increased.

Physicians' awareness of the Cochrane database in the present study was $71.8 \%$. This was higher than Hassan et al. (2014) in which only $25.9 \%$ of participants were aware (7). This was also higher than the results of Abd Al-Magied et al. (2013) in which $39.4 \%$ of participants were aware of Cochrane collaboration as a source of information about EBM (5). However, the study conducted by Rashidbeygi and Sayehmiri (2013) revealed that only $5.3 \%$ of physicians used the Cochrane database of systematic reviews. This difference could be due to the fact that EBM is still a new term in the Islamic Republic of Iran (12). In the present study, physicians' awareness of the Eastern Mediterranean Health Journal was 16.8\%, which differed studies by Hassan et al. (2014) in which $29.1 \%$ of participants were aware (7). 


\begin{tabular}{|c|c|c|c|c|c|c|c|c|}
\hline \multirow[t]{3}{*}{ Journal or database } & \multicolumn{8}{|c|}{ Awareness } \\
\hline & \multicolumn{2}{|c|}{ Unaware } & \multicolumn{2}{|c|}{ Aware but not use } & \multicolumn{2}{|c|}{ Read } & \multicolumn{2}{|c|}{$\begin{array}{l}\text { Used in decision } \\
\text { making }\end{array}$} \\
\hline & n. & $\%$ & n. & $\%$ & n. & $\%$ & n. & $\%$ \\
\hline Pubmed & 19 & 4.8 & 21 & 5.3 & 114 & 28.6 & 244 & 61.3 \\
\hline Cochrane & 112 & 28.1 & 117 & 29.4 & 129 & 32.4 & 40 & 10.1 \\
\hline EBM from BMJ * & 157 & 39.5 & 143 & 35.9 & 76 & 19.1 & 22 & 5.5 \\
\hline $\mathrm{CDC}^{* *}$ & 175 & 44.1 & 127 & 31.9 & 76 & 19.2 & 19 & 4.8 \\
\hline Clinical-evidence & 212 & 53.2 & 139 & 34.9 & 40 & 10.1 & 7 & 1.8 \\
\hline Eastern-Mediterranean health journal & 328 & 82.2 & 42 & 10.5 & 19 & 4.8 & 6 & 1.5 \\
\hline Journal of family practice & 337 & 84.7 & 54 & 13.5 & 4 & 1.0 & 3 & 0.8 \\
\hline \multicolumn{9}{|l|}{ Others reported resources } \\
\hline Medscape & \multicolumn{8}{|c|}{77 (19.3\%) } \\
\hline Up-To-Date & \multicolumn{8}{|c|}{$74(18.5 \%)$} \\
\hline E-medicine & \multicolumn{8}{|c|}{$12(3 \%)$} \\
\hline clinical key & \multicolumn{8}{|c|}{$8(2 \%)$} \\
\hline
\end{tabular}

${ }^{*}$ British Medical Journal publishing group

${ }^{*}$ Center for Disease Control and Prevention

This study indicated a generally positive attitude towards the current promotion of EBM. Boulus et al. (2013) found that $77.8 \%$ of participants had a positive attitude toward EBM (6). This was also similar to that reported by Abeysene et al. (2012) in which $75.8 \%$ of the study participants had a positive attitude towards the current promotion of EBM (13), while studies by Barghouti et al. (2009) indicated that $63.5 \%$ of participants were positive towards EBM (14).
In addition, $81.4 \%$ of participants agreed that research findings are useful in patient management. Similar results were obtained by Hassan et al. (2014), who reported that $82.3 \%$ of participants believed that research findings are useful in patient management (7). Mehrdad et al. (2012) found that $80 \%$ of participants believed that EBM is helpful in clinical decision-making (15). This result coincides with Jette et al. (2003) in which $85 \%$ of the respondents indicated they were interested in learning

\begin{tabular}{|c|c|c|c|c|c|c|c|c|}
\hline \multirow[t]{3}{*}{ Variables } & \multicolumn{6}{|c|}{ Knowledge score } & \multirow[t]{3}{*}{$\chi^{2}$} & \multirow[t]{3}{*}{$P$} \\
\hline & \multicolumn{2}{|c|}{ Poor } & \multicolumn{2}{|c|}{ Fair } & \multicolumn{2}{|c|}{ Good } & & \\
\hline & n. & $\%$ & n. & $\%$ & n. & $\%$ & & \\
\hline Gender & & & & & & & 2.290 & 0.318 \\
\hline Male $(n=213)$ & 79 & 37.0 & 116 & 54.5 & 18 & 8.5 & & \\
\hline Female $(n=185)$ & 62 & 33.5 & 99 & 53.5 & 24 & 13.0 & & \\
\hline$J o b$ & & & & & & & 113.420 & 0.001 \\
\hline Resident $(n=189)$ & 109 & 57.7 & 75 & 39.7 & 5 & 2.6 & & \\
\hline Demonstrator $(n=61)$ & 26 & 42.6 & 27 & 44.3 & 8 & 13.1 & & \\
\hline Assistant lecturer $(\mathrm{n}=148)$ & 6 & 4.0 & 113 & 76.4 & 29 & 19.6 & & \\
\hline Specialty & 76 & 33.8 & 114 & 50.6 & 35 & 15.6 & 13.752 & 0.001 \\
\hline Medical $(n=225)$ & & & & & & & & \\
\hline Surgical (n = 173 ) & 65 & 37.6 & 101 & 58.4 & 7 & 4.0 & & \\
\hline Previous qualifications & & & & & & & 57.632 & 0.001 \\
\hline Yes $(n=24)$ & 2 & 8.3 & 3 & 12.5 & 19 & 79.1 & & \\
\hline No $(n=374)$ & 179 & 47.8 & 164 & 43.8 & 31 & 8.4 & & \\
\hline Previous EBM training & & & & & & & 13.748 & 0.001 \\
\hline Yes $(n=222)$ & 60 & 27.0 & 137 & 61.7 & 25 & 11.3 & & \\
\hline No $(n=176)$ & 81 & 46.0 & 78 & 44.3 & 17 & 9.7 & & \\
\hline Total $(n=398)$ & 141 & 35.4 & 215 & 54.0 & 42 & 10.6 & & \\
\hline
\end{tabular}




\begin{tabular}{|c|c|c|c|c|c|c|}
\hline \multirow[t]{3}{*}{ Variables } & \multicolumn{4}{|c|}{ Attitude score } & \multirow[t]{3}{*}{$\chi^{2}$} & \multirow[t]{3}{*}{$\boldsymbol{P}$} \\
\hline & \multicolumn{2}{|c|}{$\begin{array}{c}\text { Negative } \\
(n=27)\end{array}$} & \multicolumn{2}{|c|}{$\begin{array}{l}\text { Positive } \\
(n=371)\end{array}$} & & \\
\hline & n. & $\%$ & n. & $\%$ & & \\
\hline \multicolumn{7}{|l|}{ Gender } \\
\hline Male $(n=213)$ & 21 & 9.9 & 192 & 90.1 & 6.786 & $0.009^{*}$ \\
\hline Female $(n=185)$ & 6 & 3.2 & 179 & 96.8 & & \\
\hline$J o b$ & & & & & 18.149 & $0.001^{*}$ \\
\hline Resident $(n=189)$ & 22 & 11.6 & 167 & 88.4 & & \\
\hline Demonstrator $(n=61)$ & 5 & 8.2 & 56 & 91.8 & & \\
\hline Assistant lecturer $(n=148)$ & 0 & 0.0 & 148 & 100.0 & & \\
\hline Specialty & & & & & 6.342 & $0.012^{*}$ \\
\hline Medical $(n=225)$ & 9 & 4.0 & 216 & 96.0 & & \\
\hline Surgical $(n=173)$ & 18 & 10.4 & 155 & 89.6 & & \\
\hline Previous qualifications and fellowships & & & & & 1.785 & 0.182 \\
\hline Yes $(n=24)$ & 0 & 0.0 & 24 & 100.0 & & \\
\hline No $(n=374)$ & 38 & 10.2 & 336 & 89.8 & & \\
\hline Previous EBM training & & & & & 18.402 & $0.001^{*}$ \\
\hline Yes $(n=222)$ & 4 & 1.8 & 218 & 98.2 & & \\
\hline No $(n=176)$ & 22 & 11.0 & 154 & 89.0 & & \\
\hline Total & 27 & 6.8 & 371 & 93.2 & - & - \\
\hline
\end{tabular}

and improving their skills of implementing evidencebased practices (16).

This study indicated that $89.9 \%$ of participants agreed that practicing EBM improve patient outcomes. Studies by Hassan et al., (2014) indicated that $90 \%$ of participants also believed that EBM would improve patient outcomes (7), but was higher than studies by Risahmawati (2011) in which $65 \%$ of participants said that EBM improve patient care (10).

Over one half of participants (55.8\%) attended courses in EBM. This differed from Hassan et al. (2014) who reported only $18.2 \%$ of participants attending EBM courses (7), or Boulus et al. (2013) at 7.2\% (6). This could be explained by the younger age of the target group included in those studies, namely graduated residents with high workloads and thus little chance of attending courses, especially those not integral in their postgraduate study. This differs from the results of Ismail et al. (2011) in which the percent was $10.9 \%$ attending EBM courses (17). This difference can be attributed to the fact that EBM was one of the postgraduate elective courses in Tanta Faculty of Medicine.

Regarding critical appraisal courses, only $6.8 \%$ of the current study participants reported attending them. Nearly similar results were obtained by Hassan et al. (2014) in which $10 \%$ of participants attended critical appraisal courses (7). Our results were higher than that reported by Boulus et al. (2013) in which only $4 \%$ attended critical appraisal courses (6). A relatively higher percentage was obtained by Ismail et al. (2011) at 19.1\% attending such courses (17). This could be attributed to the fact that the age of the participants ranged from 23 to 57 years old and included lectures and assistant professors.

Most physicians (97\%) in our study had access to the World Wide Web, while studies by Hassan et al. (2014) indicated that $95.5 \%$ of participants had accessibility (7). Our results were higher than those of Boulus et al. (2013) and Ismail et al. (2011) in which only $60 \%$ and $46 \%$ respectively had accessibility $(6,17)$. In addition, $87.6 \%$ of participants reported that World Wide Web searches influenced their practice. This was higher than Hassan et al. (2014) in which $60 \%$ of the participant had used World Wide Web searches in clinical decision-making (7).

In this study, $73.1 \%$ reported reading medical journals as follows: $28.3 \%$ read occasionally, $26.6 \%$ read on demand, and $18 \%$ read regularly. This differed from Hassan et al. (2014) in which $42.8 \%$ reported reading medical journals (7), while Al-Kubaisi et al. (2010) reported that one third of participants were reading journals regularly, another third were reading on demand, and $28 \%$ were reading occasionally (11). Our study indicated that $33.2 \%$ of participants reported more than $50 \%$ of their practice was evidence based. This differed from Hassan et al. (2014) in which $66.1 \%$ reported more than $50 \%$ of their practice was evidence based (7).

\section{Barriers towards EBM application}

Our study revealed that the major barriers reported by study participants were as follows: patient overload, lack of time, colleagues' attitudes, lack of skills, and the fear of criticism. According to Abd Al-Magied et al. (2013), the first barrier to practicing EBM for most family physi- 


\begin{tabular}{|c|c|c|}
\hline Variables & $(n=398)$ & $\%$ \\
\hline Attendance of EBM courses & 222 & 55.8 \\
\hline Critical appraisal training & 27 & 6.8 \\
\hline \multicolumn{3}{|l|}{ Accessibility to World Wide Web } \\
\hline No Accessibility & 12 & 3.0 \\
\hline Home & 358 & 89.9 \\
\hline Faculty Library & 147 & 36.9 \\
\hline Mobile & 171 & 43.0 \\
\hline Using World wide web in clinical decision & 349 & 87.7 \\
\hline Reading medical journal & 291 & 73.1 \\
\hline \multicolumn{3}{|l|}{ Frequency of reading journals } \\
\hline Occasionally & 113 & 28.4 \\
\hline On demand & 106 & 26.6 \\
\hline Regularly & 72 & 18.1 \\
\hline \multicolumn{3}{|l|}{ Practice percentage } \\
\hline o- & 43 & 10.8 \\
\hline $25^{-}$ & 174 & 43.7 \\
\hline $50-$ & 97 & 24.4 \\
\hline $75-100$ & 35 & 8.8 \\
\hline \multicolumn{3}{|l|}{ Methods to move towards EBM } \\
\hline EBM integration into undergraduate course & 300 & 75.4 \\
\hline Training physicians to use EBM & 335 & 84.2 \\
\hline Case review and discussion held in each department & 349 & 87.7 \\
\hline \multicolumn{3}{|l|}{ Major barriers to practice EBM } \\
\hline Patient overload & 271 & 68.1 \\
\hline Lack of time & 239 & 60.1 \\
\hline Colleagues' attitudes & 187 & 47.0 \\
\hline Lack of skills & 186 & 46.7 \\
\hline Fear of criticism by senior staff & 177 & 44.5 \\
\hline No financial gain & 151 & 37.9 \\
\hline Insufficient resources & 87 & 21.9 \\
\hline Don't believe in EBM & 34 & 8.5 \\
\hline
\end{tabular}

\begin{tabular}{|c|c|c|c|c|c|c|c|c|}
\hline \multirow[t]{3}{*}{ Variables } & \multicolumn{6}{|c|}{ Practice score } & \multirow[t]{3}{*}{$\chi^{2}$} & \multirow[t]{3}{*}{$P$} \\
\hline & \multicolumn{2}{|c|}{ Poor } & \multicolumn{2}{|c|}{ Fair } & \multicolumn{2}{|c|}{ Good } & & \\
\hline & n. & $\%$ & n. & $\%$ & n. & $\%$ & & \\
\hline Gender & & & & & & & 1.977 & 0.372 \\
\hline Male $(n=213)$ & 125 & 58.7 & 74 & 34.7 & 14 & 6.6 & & \\
\hline Female $(n=185)$ & 108 & 58.4 & 58 & 31.4 & 19 & 10.2 & & \\
\hline$J o b$ & & & & & & & 64.267 & $0.001^{*}$ \\
\hline Resident ( $n=189$ ) & 138 & 73.0 & 49 & 25.0 & 2 & 1.1 & & \\
\hline Demonstrator $(n=61)$ & 42 & 68.9 & 16 & 26.2 & 3 & 4.9 & & \\
\hline Assistant lecturer ( $n=148)$ & 53 & 35.8 & 67 & 45.3 & 28 & 18.9 & & \\
\hline Specialty & & & & & & & 9.597 & $0.008^{*}$ \\
\hline Medical $(n=225)$ & 134 & 59.6 & 65 & 28.9 & 26 & 11.6 & & \\
\hline Surgical ( $n=151$ ) & 99 & 57.2 & 67 & 38.7 & 7 & 4.0 & & \\
\hline Previous qualifications & & & & & & & 1.830 & 0.400 \\
\hline Yes $(n=24)$ & 17 & 70.8 & 5 & 20.8 & 2 & 8.4 & & \\
\hline No $(n=374)$ & 216 & 57.8 & 127 & 34.0 & 31 & 8.3 & & \\
\hline Total $(n=398)$ & 233 & 58.5 & 132 & 33.2 & 33 & 8.3 & & \\
\hline
\end{tabular}

*Significant 


\section{Connaissances, pratiques et attitudes des médecins à l'égard de la médecine factuelle en Égypte}

\section{Résumé}

Contexte: La médecine factuelle aide les médecins à mieux gérer la surabondance d'informations, à répartir les ressources de santé de façon plus équitable, à réduire les dépenses de soins de santé et à justifier leurs choix thérapeutiques vis-à-vis du grand public.

Objectifs : La présente étude visait à évaluer les connaissances, les pratiques et les attitudes des médecins de l'hôpital universitaire de Tanta (Égypte) vis-à-vis de la médecine factuelle.

Méthodes : Une étude transversale a été conduite. Les données ont été recueillies par le biais d'un questionnaire autoadministré distribué à 398 médecins de différentes spécialités au cours de l'année 2017.

Résultats : Le taux de réponse était de 93,6\%. Plus de la moitié des participants (61,3\%) indiquaient utiliser PubMed lors de leurs prises de décisions. Les médecins ayant une solide connaissance de la médecine factuelle représentaient $10,5 \%$ des participants, alors que $54 \%$ déclaraient avoir d'assez bonnes connaissances dans ce domaine et 35,5\% des connaissances limitées. Concernant les attitudes à l'égard de la médecine factuelle, 76,4\% des participants à l'étude se félicitaient de la promotion qui en est fait actuellement, 81,4\% pensaient que l'utilisation des résultats d'études dans la prise en charge quotidienne des patients est utile et $89,9 \%$ estimaient que la pratique de la médecine factuelle améliore les résultats obtenus chez les patients. Plus de la moitié des participants (55,8\%) avaient suivi des cours en lien avec la médecine factuelle mais seulement 6,8\% avaient été formés à l'évaluation critique. La majorité des répondants (97\%) avaient accès au Web. Les obstacles identifiés comme un frein à la pratique de la médecine factuelle étaient la surcharge de patients (68,1\%), le manque de temps (60,1\%), l'attitude des confrères (47\%), l'insuffisance des compétences (46,7\%) et la peur des critiques (44,5\%).

Conclusions : La plupart des participants à la présente étude ont une attitude positive à l'égard de la médecine factuelle, mais en ont une pratique insuffisante malgré des connaissances solides en la matière. La médecine factuelle devrait être intégrée dans les cursus d'études universitaires et postuniversitaires, et des formations devraient être proposées aux résidents afin qu'elle soit appliquée de façon adéquate dans la pratique quotidienne.

$$
\begin{aligned}
& \text { معلومات واتجاهات وممارسات الأطباء تجاه الطب الـمُسنَّد بالبر اهين في مصر }
\end{aligned}
$$

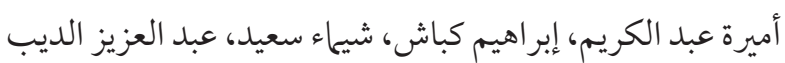

الخالاصة

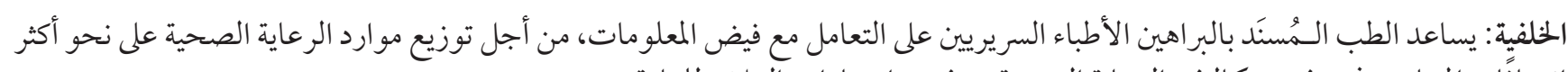

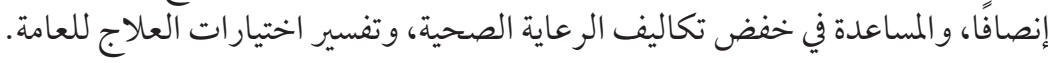

الأهداف: هدفت هذه الدراسة إلى تقييم المعلومات والاتجاهات والملمارسات تجاه الطب الـمُسنَّ بالبراهين بين الأطباء في مستشفى جامعة طنطا، بمدينة طنطا، مصر مافر هـ

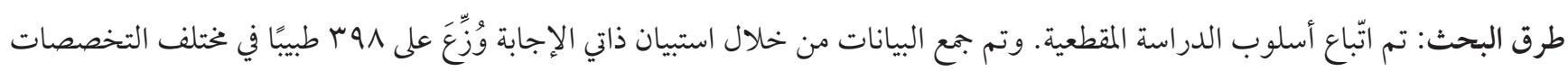

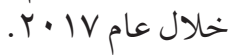

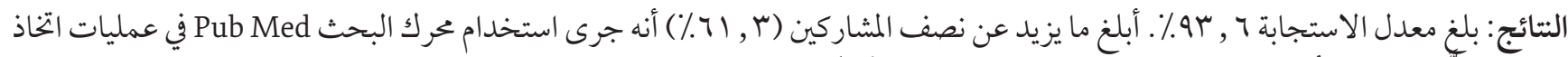

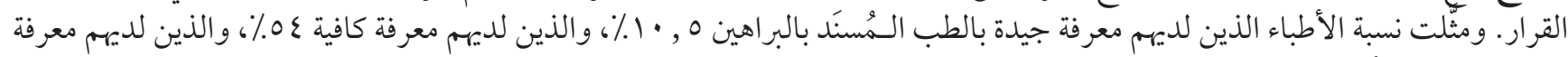

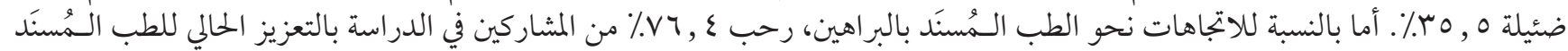

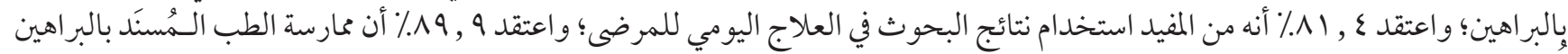

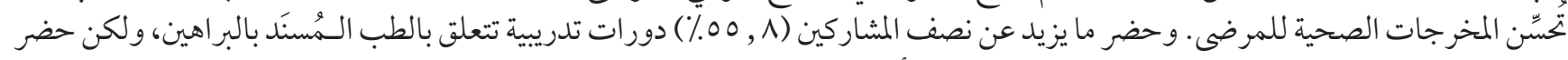

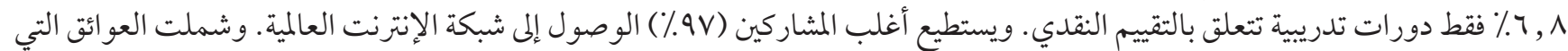

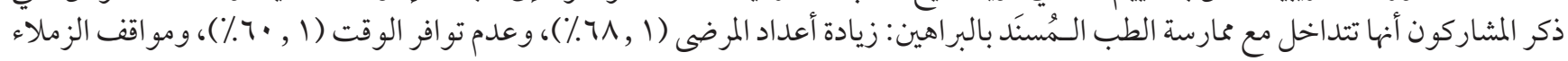

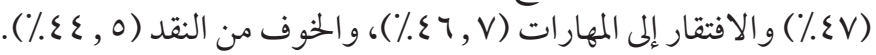

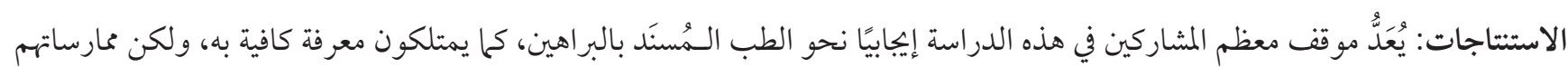

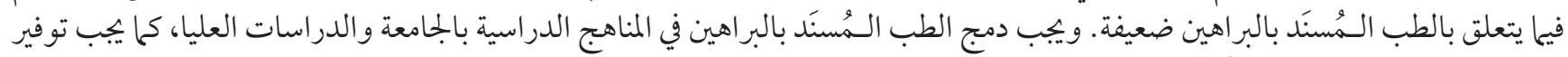

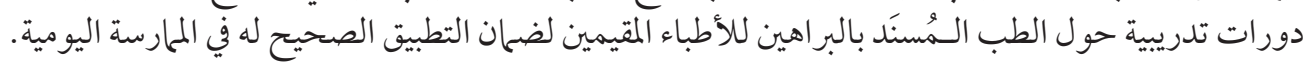




\section{References}

1. Shelton JB, Saigal CS. The crossroads of evidence-based medicine and health policy: implications for urology. World J Urol. 2011;29(3):283-9. http://dx.doi.org/10.1007/s00345-010-0643-2

2. Haynes RB. Of studies, syntheses, synopses, summaries, and systems: the " $5 \mathrm{~S}$ " evolution of information services for evidence-based healthcare decisions. Evid Based Med J. 2006;11(6):162-4. DOI: 10.1136/ebm.11.6.162-a

3. Straus SE, Richardson WS, Glasziou P, Haynes RB. Evidence-based medicine: How to practice and teach EBM. 4th ed. Edinburgh: Churchill Livingstone; 2005.

4. Crawford JM. Original research in pathology: judgment, or evidence-based medicine? Lab Invest. 2007;87(2):104-14. http://dx.doi. org/10.1038/labinvest.3700511

5. Abd AL-Magied DA, and Abd El-Aziz KM. Knowledge, attitudes and practices of evidence-based medicine among family physicians in Menoufia Governorate, Egypt. 2013; Thesis in family medicine submitted to Ain Shams Faculty of Medicine, Ain Shams University, Egypt.

6. Boulos DN, Hussein RS, El Damaty SI, AlGhazaly S. Ain Shams University residents' knowledge, attitudes, and barriers to practice evidence based medicine. EJCM. 2013;31(1):37-49. DOI: 10.12816/0011932

7. Hassen HA, Dawa AA, Afifi RH. Impact of implementation of evidence based medicine educational program on Knowledge, attitudes and practice of physicians in Benha University Hospitals.2014; Thesis in Medicine submitted to Benha Faculty of Medicine. Benha University.

8. Tanta University Information and Statistics Unit. Annual records of physician numbers and patient admission rates. 2016.

9. McColl A, Smith H, White P, Field J. General practitioners' perceptions of the route to evidence based medicine: a questionnaire survey. BMJ. 1998;316(7128):361-5. http://dx.doi.org/10.1136/bmj.316.7128.361

10. Risahmawati RR, Emura SS, Nishi TT, Koizumi SS. Japanese resident physicians' attitudes, knowledge, and perceived barriers on the practice of evidence based medicine: A survey. BMC Res Notes. 2011;4(1):374. http://dx.doi.org/10.1186/1756-0500-4-374

11. Al Kubaisi N, Al Dahnaim L, Salama R. Knowledge, attitudes and practices of primary health care physicians towards evidence-based medicine in Doha, Qatar. East Mediterr Health J. 2010;16(11):1189.

12. Rashidbeygi M, Sayehmiri K. Knowledge and attitudes of physicians towards evidence based medicine in Ilam, Iran. Iran Red Crescent Med J. 2013;15(9):798-803. http://dx.doi.org/10.5812/ircmj.7204

13. Abeysena C, Jayawardana P, Wickremasinghe R, Wickramasinghe U. Evidence $\square$ based medicine knowledge, attitudes, and practices among doctors in Sri Lanka. Evid Based Med J. 2010;3(2):83-7. doi.org/10.1111/j.1756-5391.2010.01077.x

14. Barghouti F, Halaseh L, Said T, Mousa AH, Dabdoub A. Evidence-based medicine among Jordanian family physicians: awareness, attitude, and knowledge. Can Fam Physician. 2009;55(7):6-13.

15. 15. Mehrdad N, Joolaee S, Joulaee A, Bahrani N. Nursing faculties' knowledge and attitude on evidence-based practice. Iranian J Nurs Midwifery Res. 2012;17(7):506.

16. Jette DU, Bacon K, Batty C, Carlson M. Evidence-based practice: beliefs, attitudes, knowledge, and behaviors of physical therapists. Physiother Res Int. 2003;83(9):786.

17. Ismail N, Abouseif H, El Damaty SI. Evidence based medicine, awareness and attitude among physicians in Ain Sham Ain Sham University hospitals. Egypt J Community Med. 2011;29:12. 